\title{
新潟県におけるヌカカの観察11
}

\section{Notes on Culicoides (Diptera: Ceratopogonidae) in Niigata Prefecture, Japan}

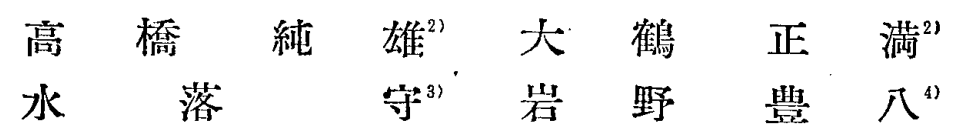

Sumio Takahashi, Masamitsu Otsuru, Mamoru Mizuochi and Toyohachi Iwano

\section{まえがき}

わが国に括けるスカカの分類学的研究は，素木，德 永，河野，高橋らによって進められてきたが，最近に至 つて国内の数地方に抬いてその分布や被害の実状につい ての調查がかなり活発に行わ机るょうになつた。

今回，著者ら新潟県に扣いてメカカの分布調查さ県 内でその被害が著しいといわれている東䅡城郡の1地区 に括ける実態調查学行う機会学得をので，こ〉にそれら の知見导報告したい。

\section{新潟県におけるヌカカの分布調查}

\section{1. 調查の概要}

期間：昭和 31 年 5 月 10月

場所：新潟市, 西蒲原郡, 加茂市, 中蒲原郡, 南浦原 郡, 北魚沼郡, 三島郡, 中䅡城郡, 東頚城郡, 直江津市, 高田市扮よび佐渡郡の 4 市 8 郡.

方法：Light trap 已電燈用虫取りカバーによる夜間 採集捛よび捕虫網さ吸虫管による Biting collection.

\section{2. 探集したヌカカの種類}

前述の方法により，各地で採集したヌカカをCulicoldes 属のみについて分類した成績は表1の通りである。

これらのらち，C. erairai 沙河野，高橋 (1940) が北 海道柇幌市で採集し，新種 として発表したもので，岡 田 (1941) 攼岩手県で, 正塭 (1953) 快京都で, 長花, 外山（1956）は米子市で採集している.C. matsuzawai は徳永 (1950) が九州の宮崎県で採集し, 新種さして発 表したもので同地方以外の分布は明ら功な゙尔つた。

1) 本諭文の要旨は日本衛生動物学会第 9 回大会に抽 いて発表した。

2) 新潟大学医学部医動物学教室

Department of Medical Zoology, Niigata University School of Medicine

3) 新潟目裳生部

Health Department, Niigata Prefecture Government Office

4) 新潟県大島保健所

Oshima Health Center, Niigata Prefecture
C. odibilis は従来欧州にのみ分布しているものとされて いたが上野，北岡ら（1956）浊東京都下小平町で採集し た. C. ponkikiri は河野, 高憍 (1940) が北海道札虓市 で採集し, 新種として発表したもので, 高橋 (1941) ば 満州にも分有していることを明らかにした。. C. sitino-

表 1 List of Culicoides (Diptera : Ceratopogonidae) Niigata Prefecture, 1956

1) Culicoides arakawae Arakawa, 1910 (ara:)

2) C. arcuatus Winnertz, 1852 (arc.)

3) C. aterinervis Tokunaga, 1937 (ate.)

4) C. circumscriptus Kieffer, 1918 ((cir.)

5) C. erairai Kono et Takahasi, 1940 (era.)

6) C. matsuzawai Tokunaga, 1950 (mat.)

7) C. odibilis Austen, 1921 (odi.)

8) C. pictimargo Tokunaga et Shogaki, 1953 (pic.)

9) C. ponkikiri Kono et Takahasi, 1940 (pon.)

10) C. pulicaris Linnaeus, 1758 ( $p u l$. )

11) C. sigaensis Tokunaga, 1937 (sig.)

12) C. sitinohensis Okada, 1941 (sit.)

13) C. unguis Tokunaga, 1940 (ung.)

14) C. sp

hensis は岡田（1941）が青森県七戸で採集し, 新種とし て発表したもので東北地方以外の分布深明らかでなかつ た. これらの他，C. arakawae, C. arcualus, C. aterinervis, C. circumscriptus, C. pictimargo, C. pulicaris 招 ょび C. sigaensis について德永 $(1937,1940)$ 以し 的数人の研究者によつて本邦内の数地方古るい社多くの 地方に分布しているここが明ら办にされている．C. sp。 は現在检訶中のものである。

\section{3. 分布状況}

採集した Culicoides 属14種の地域別分布状況は図 1 通りである. 新潟市には C. arakawae 学主さする 3 種 西蒲原郡には C. arakawae 1 種, 加茂市には C. arckawae 主主さする 6 種, 中蒲原郡には C. arakawae 学 主さする3 種，南蒲原郡に注 C. arakawae 学主とする。 7 種, 北魚沼郡でね C. matsuzawa 学主さする 6 種, 
表 2 地域別採集記 録

\begin{tabular}{|c|c|c|c|c|c|}
\hline \multirow{2}{*}{ 採集 地 } & \multirow{2}{*}{ 期間 } & \multicolumn{3}{|c|}{ 採集したヌカカ } & \multirow{2}{*}{ 探集法3) } \\
\hline & & 種類 ${ }^{11}$ & 採集 & 数 ${ }^{22}$ & \\
\hline 新 潟 市 & 7 月中旬 & $\begin{array}{l}\text { ara. } \\
\text { mat. } \\
\text { cir. }\end{array}$ & $\begin{array}{r}27 \\
2 \\
1\end{array}$ & & $\mathrm{C}$ \\
\hline 西蒲原郡 & 7 月中旬 & ara. & 80 & 46 & $\mathrm{C}$ \\
\hline 加茂 市 & $\begin{array}{l}7 \text { 月中旬 } \\
\sim 10 \text { 中旬 }\end{array}$ & $\begin{array}{l}\text { ara. } \\
\text { sig. } \\
\text { odi. } \\
\text { sit. } \\
\text { ate. } \\
\text { cir. }\end{array}$ & $\begin{array}{r}352 \\
249 \\
7 \\
2 \\
2 \\
1\end{array}$ & $\begin{array}{r}200 \\
7 \\
1\end{array}$ & $\mathrm{C}$ \\
\hline 中蒲原郡了 & $\begin{array}{l}7 \text { 月中旬 } \\
\sim 8 \text { 月上旬 }\end{array}$ & $\begin{array}{l}\text { ara. } \\
\text { odi. } \\
\text { sig. }\end{array}$ & $\begin{array}{r}26 \\
3 \\
1\end{array}$ & $\begin{array}{l}3 \\
\mathbf{1}\end{array}$ & $\mathrm{C}$ \\
\hline 南蒲原郡 & 6 月 & $\begin{array}{l}\text { ara. } \\
\text { sig. } \\
\text { ate. } \\
\text { odi. } \\
\text { sit. } \\
\text { era. } \\
\text { mat. }\end{array}$ & $\begin{array}{r}201 \\
78 \\
58 \\
8 \\
5 \\
1 \\
1\end{array}$ & $\begin{array}{r}\mathbf{2 5} \\
\mathbf{3} \\
\mathbf{2}\end{array}$ & $\mathrm{C}$ \\
\hline 北魚沼郡 & 8 月中旬 & $\begin{array}{l}\text { mat. } \\
\text { sig. } \\
\text { ara. } \\
\text { ate. } \\
\text { odi. } \\
\text { sit. } \\
\text { C. sp. }\end{array}$ & $\begin{array}{r}43 \\
22 \\
20 \\
10 \\
2 \\
1 \\
1\end{array}$ & & $C+L$ \\
\hline 三 島 郡 & 8 月上旬 & $\begin{array}{l}\text { ara. } \\
\text { odi. }\end{array}$ & $\begin{array}{l}6 \\
3 \\
\end{array}$ & & $\mathrm{C}$ \\
\hline 中頸城郡 & $\begin{array}{l}6 \text { 月上旬 } \\
\sim 9 \text { 月旬 }\end{array}$ & $\begin{array}{l}\text { ara. } \\
\text { odi. } \\
\text { cir. } \\
\text { sit. } \\
\text { ate. } \\
\text { sig. }\end{array}$ & $\begin{array}{r}778 \\
38 \\
1 \\
1\end{array}$ & $\begin{array}{r}212 \\
5 \\
\\
1 \\
\mathbf{1}\end{array}$ & C \\
\hline 東頸域郡 & $\begin{array}{l}5 \text { 月中旬 } \\
\sim 8 \text { 月中旬 }\end{array}$ & $\begin{array}{l}\text { cir. } \\
\text { odi. } \\
\text { sig. } \\
\text { ara. } \\
\text { arc. } \\
\text { ung. }\end{array}$ & $\begin{array}{r}487 \\
39 \\
22 \\
2 \\
3 \\
1\end{array}$ & $\mathbf{5}$ & B \\
\hline 直江津卢 & $\begin{array}{l}\text { 7月下旬 } \\
\sim 9 \text { 月上旬 }\end{array}$ & $\begin{array}{l}\text { ara. } \\
\text { odi. }\end{array}$ & $\begin{array}{r}40 \\
1\end{array}$ & 24 & C \\
\hline 高田市 & $\begin{array}{l}8 \text { 月上的 } \\
\sim 9 \text { 中旬 }\end{array}$ & $\begin{array}{l}\text { ara. } \\
\text { odi. }\end{array}$ & $\begin{array}{r}96 \\
1 \\
\end{array}$ & 5 & $\mathrm{C}$ \\
\hline 佐 渡 郡 & 7 月中旬 & $\begin{array}{l}\text { pic. } \\
\text { cir. } \\
\text { ara. } \\
\text { pon. } \\
\text { pul. } \\
\text { sig. }\end{array}$ & $\begin{array}{r}56 \\
21 \\
4 \\
1 \\
1 \\
1\end{array}$ & $\begin{array}{r}3 \\
14\end{array}$ & $\mathrm{C}+\mathrm{L}$ \\
\hline
\end{tabular}

註 1) 種名は表1に示されるよらに略称する.

2) ロマン体は雌, ゴヂック体は雄の採集数 を示导。

3） Cは虫取りカバー，上はライト・トラッ プ，Bは人据とりで吸虫管捕虫網による 採集方法を示す。
三島郡に结，C. arakawae 军主とする 2 種, 中頚城郡に 洨 C. arakawae 字主とする 6 種, 東䅡城郡には C. circumscriptus を主己寸る 6 種, 直江津市と高田市は共に C. arakawae 字主亡する 2 種, 佐渡郡には C. pictimar go 定主さする6 種が分布している. とれらの種類別採. 集記録は表 2 の通りで㐫る。

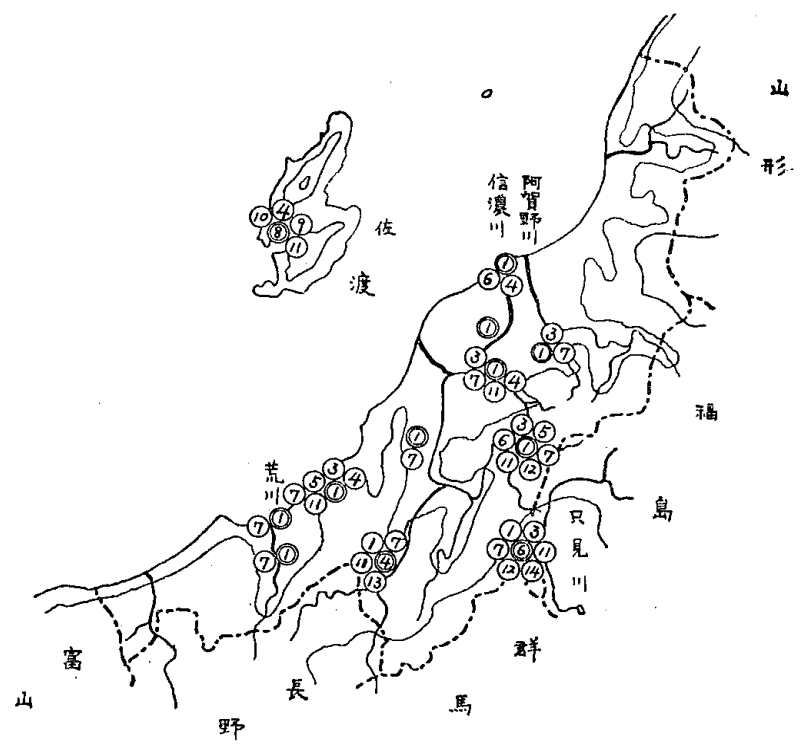

図 1 新潟県に和けるヌカカの分布状況

註 1) 円内の数字は趇 1 の番号に同じ。

2) (ほは，その地域での優占種を示す。

概して沿岸の平野部招よび内陸の丘陵部では C.arakaー wae が優占して招り，東頝城郡の1地区（後述）および 佳渡の海岸部では． C. circumscriptus が多数採集された。 染た山間部である福島県境の奥只見方面では C. matsuzawai が多数採集された.

尚分類に際して，C. aterinervis，C. pictimargo 抢 び C. sigaensis の同定は徳永雅明博士の厚意にょる。

\section{新潟県松之山地方におけるヌわカ による被害状況と分布種の調査}

新潟県東頝城郡烃亡山村の特に牙口温泉地区は，又カ カによる被害の莧しいこころである。同地方虻本邦でも 指折りの豪雪地帯で，冬季は軒肎越える積雪のため交通 が杜絶し，陸の孤島とまでいわれている。

この地方でノッコチ，ショッカ，ベベガなごと呼ばれ ているヌカカの活動心, 雪解けの5月初旬から始泉り, 雪の降り始める11月初頃迄及られる. 被害の最も甚し い㭙期《 5 月から 6 月にかけて，特に田植時で，体の日 蒢の部分へ蝟集し，肌着の下队毛髮の中へも潜入して刺? 咬する.一般に力，ブニなざよりも刺咬時の痛及訬少い が，後遺症が大であるさいう。杰量天のむし暑い日に。 来襲が著しいこのととである。

著者らの今回の観察结 5 月下旬から 7 月中旬にかけて 
表 3 要口温泉に扣けるヌカカの採集記録（昭和31年 7 月）

\begin{tabular}{|c|c|c|c|c|}
\hline \multirow{2}{*}{ 採集月日(時刻) } & \multirow{2}{*}{ 採集方法 } & \multicolumn{3}{|c|}{ 採集したヌ力 力 } \\
\hline & & 種 & 性別 & 匹 数 \\
\hline $7.10(1930 \sim 2000)$ & 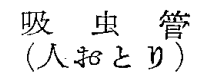 & $\begin{array}{l}\text { C. circumscriptus } \\
\text { C. odibilis }\end{array}$ & $\begin{array}{l}\text { 운 } \\
\text { 우 }\end{array}$ & $\begin{array}{r}193 \\
1\end{array}$ \\
\hline "I $\quad(2300 \sim 2330)$ & $\begin{array}{l}\text { 咒虫管 } \\
\text { (室内電登) }\end{array}$ & $\begin{array}{l}\text { C. circumscriptus } \\
\text { C. arakawae }\end{array}$ & $\begin{array}{l}\text { 우 } \\
\text { i }\end{array}$ & $\begin{array}{r}123 \\
1 .\end{array}$ \\
\hline $7.16(2000 \sim 2030)$ & $\begin{array}{l}\text { 吸 虫 管 } \\
\text { (人民り) }\end{array}$ & C. circumscriptus & 우 & 103 \\
\hline $7.21(1930 \sim 2000)$ & $\begin{array}{l}\text { 吸 虫 管 } \\
(\text { 人拓とり) }\end{array}$ & $\begin{array}{l}\text { C. circumscriptus } \\
\text { C. odibilis }\end{array}$ & $\begin{array}{l}\text { 우 } \\
\text { 우 }\end{array}$ & $\begin{array}{r}100 \\
1\end{array}$ \\
\hline$" \quad(2000 \sim 2015)$ & $\begin{array}{l}\text { 吸 虫 } \\
\text { 㥃 管 }\end{array}$ & $\begin{array}{l}\text { C. circumscriptus } \\
\text { C. odibilis }\end{array}$ & $\begin{array}{l}\text { 우 } \\
\text { 웅 }\end{array}$ & $\begin{array}{r}182 \\
1\end{array}$ \\
\hline
\end{tabular}

廃湯溝内の又カ力幼虫の分有状 況は，流し口の下方約70 m附近方. ら300 mぐらい䒠での間に最も密 であるが，流し口附近定始め廃湯 溝の全域に亘つて発生している。 又カカ幼虫は，との廃湯溝の泥䏫 中に無数に発生して招り，一守く いの泥中に多数の淡黄白色 $5 \mathrm{~mm}$ 前後, 䄅状の幼虫が盛んに振動し ているのが認められる。底泥上に は監蕰類や硫黄バクテリアが繁殖 している.びやくこピペツト定 用いて多数のヌカカ幼虫定採集し

主として雨口温泉地区に拐いて数回実施された。 日週活 動で注，日中よりも日没時に活動の山がみられ，夜間室 内でも相当数のメカカが採集された。

さて本地区で採集されたヌカカの種類以殆どが C. cir cumscriptus で, 他炕 C. arakawae，C. odibilis 招よび C. sigaensis の3 種が少数で牥あるが採集された。加害

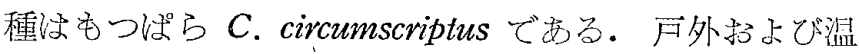
泉宿の室内に扰方吸虫管之捕虫網による Biting collection（人扢とり）の成績学示すと表 3 の通りである.

次にこの地区に打けるメカカの主要発生源定調查した ところ, 温泉の廃湯学附近の泚海川几導くため, 山の斜 面に沿つて作られた幅約 $50 \mathrm{~cm}$, 延長約 $1,500 \mathrm{~m}$ に亘る 廃湯溝(四 2 ) 飞限局して多数のヌカカ幼虫索検出した. この温泉の成分法大島保健所の梌查に上ると稀食塩泉で

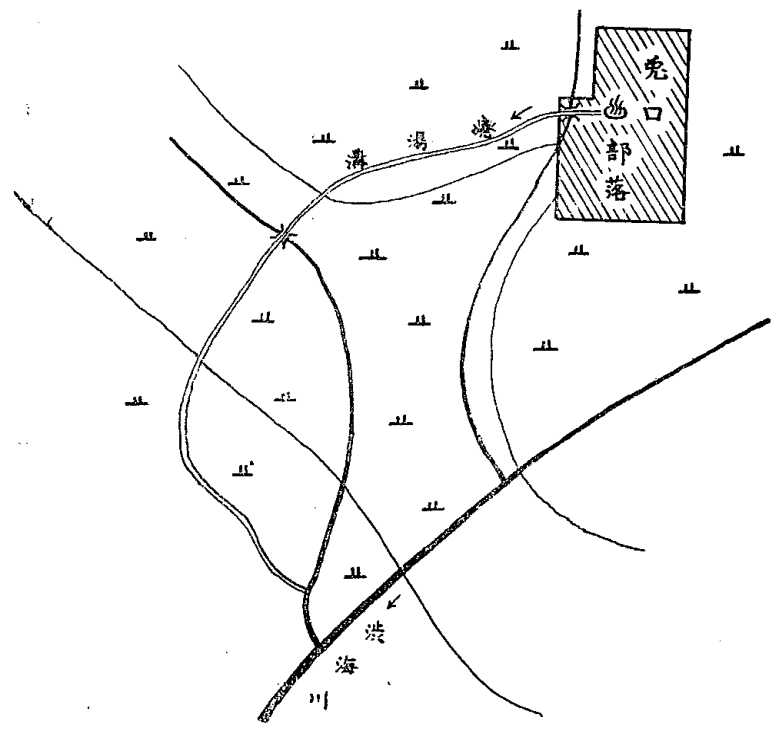

図 2 兔口温泉附近の略図

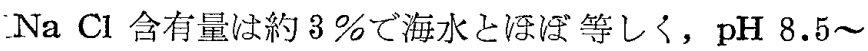
10.0の強アルカリ性を示す. 廃湯の温度怯, 流し口附近 で $36.5^{\circ} \mathrm{C}$, 廃湯溝の中流では $25^{\circ} \mathrm{C}$ 前後である.
て分類堂: 行つたとしろ, その殆どが C. circumscriptus の幼虫であり，他仯数の未同定の幼虫 1 種が混棲して いるととがわかつた. 本地区に扔けるヌカカの被害性一 般にこの廃湯溝に沿了带状の地域に限られているょうで 亦る。

な扢との廃湯溝に棲息ずるヌカカ幼虫駆除の予備字験 として, ブニ幼虫駆除法に潐じ, これに底泥の擋拌操作 学加光, 10 40 ppm (1 分間流水量) の DDT (ペスト）学使用したが, 殆ど効果学認めるととが出来なか 灾.

\section{まとめ}

炤和31年 5 月から10月まで新潟紧内の 4 市 8 郡に扮い て主に Light trap と電燈用虫取りカバーによる夜間採 集，1 部の地区では Biting collection(人㧍とり) 学行 つて，又カカの分布調查定実施した。採集したヌカカは Culicoides 属について分類学行い, C. arakawae, C. arcuatus, $C$. aterinervis, C. circumscriptus, C. erairai, $C$. matsuzawai, C. odibilis, C. pictimargo, C. ponkikiri, C. pulicaris, C. sigaensis, C. sitinohensis 拈よび C. unguis の13種, 他に未同定の 1 種, 計14種学認めた. とれらの メカカの分布状況は，海岸飞沿う平野部稆よびこれにつ づく丘陵地帯では，C. arakawae が優占し，東䫋城郡の 稀食塩泉地带招よび佐渡の海岸部では C. circumscriptus が多数它占めていた。 また山間の福島県に接抽る奥只見 万面では，C. matsuzawai が多数採集された.

特に県内でメカカによる被害の著しいここで知られて 心る東䅡城郡松之山村の温泉地滞に㧈いては，被害の実 熊乞幼虫の調查定併せて行つた。同地で昼，夜間に人お とり採集で得られたヌカカを調べたととろ，C. circumscriptus が主要種であるととがわからた。 その日週活動 は日中よりも，日没時に来襲の山が認められ，夜間にも 人家内へ侵入刺㖫与ると学知つた。 
との地区に都けるメカカの主要発生源虻，温泉の廃湯 定川へ流寸ために設けられ幅約 $50 \mathrm{~cm}$, 延長約 1,500 mの廃湯溝で, 多数のC. circumscriptus 幼虫がその泥 林中方採集された。抬との廃湯は $\mathrm{Na} \mathrm{Cl}$ 含有量約 $3 \%, \mathrm{pH} 8.5 \sim 10.0$, 廃湯の温度は流し口附近 $36.5^{\circ} \mathrm{C}$, 中流 $25^{\circ} \mathrm{C}$ 前後である.

\section{参考交献}

1) 荒川重理 (1910) : 家鶏の新害虫才ホヌカカ(Ceratopogon arakawae Matsumura)に就て. 昆虫世界, 14(8): 3-6. - 2) Arnaud, P. (1956): The Heleid Genus Culicoides in Japan, Korea and Ryukyu Islands (Insecta, Deptera). Mic. Ent., 21 (3) : 84-207. -3) Edwards, F. W. (1939): The genitalia of British Culicoides with notes on synonymy. British Blood Sucking Flies, 129-152, British Museum (Natural History), London. -4) 藤戸力 (1939)：木浦ヌカ ガ Culicoides miharai Kinoshita の砸究. 第一報, 㖬性及び分布. 朝鮮医学会雑誌, 29(5)：687-696.5) 藤戸力 (1939) : 第二報, 飛翔出現の経過消長. 朝 鮮医学会雑誌, 29(6)：923-940. 一6) 藤戸力 (1942) : 第三報，又力カ幼虫及び蛹の飼育兹びに其の成績に 就て。朝鮮医学会雑誌，32(5)：529-535. 一7) 藤戸 力 (1942): 第四報, ヌカ力幼虫及び蛹の形態に就て. 朝鮮医学会雑誌，32（11）：955-969. -8）藤戸力 (1944）：第五報，木浦ヌカ力の産卵睬化の経過並び

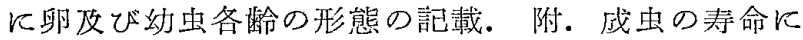
就いて。朝鮮医学会荍誌，33(1)：57-70，一9）藤戸 力 (1944)：第六報，木浦又力力幼虫の干潟原中の分 布及び周年棲息状況の調查. 朝鮮医学会雑誌, $\mathbf{3 3}(2)$ 75－86．－10）藤戸力 (1944）：第七報，木浦又力力防 除飞関与る研究. 朝鮮医学会萑誌, 33(3) : 155-181. 一11）木下周太 (1918)：朝鮮磨吸血性「クリコイデ ス」に就をて。動物学雑誌, $354:$ 155-160. -12) Kono, H. \& Takahasi, H. (1940): A revision of the $C$ ulicoides-SFecies of Saghalien and Hokkaido (Ceratopogonidae, Diptera). Ins. Mats., 3(2。 3）：69-77. 一-13）森川国康 (1956)：松山书内のヌ力 力類火関する知見. 衞生動物, 7 (3・4)：256-257. -14) 長花操，外山宽樹 (1956)：米子市に於てラィ トトラップにより採集しそ棣蚊の種類乙季節的消長. 衛生動物, 7 (2) : 117. - 15) Okada, T.：Biting midge collected from the north-eastern district of Honsyu, Japan. Jour. Col. Agr., Tokyo Imp. Univ., 15(1) : 13-31. 一16) 佐々学 (1950) : ヌカカ. 疾病之動物, 64-69, 岩波書店, 東京. - 17) 素木得一 (1913)：一般衛生害虫飞関する調查. 台湾総督府農 事試験場特別報告， 8：286-297。 -18）正垣幸男 (1953)：京都に於て Light-trap で得たヌカカの季 節的消長とニワトリヌカカの翅の斑紋型頻度に就い て. 衞生動物, $4(1 \cdot 2): 5 .-19)$ Takahasi, H. :
Notes on some species of the Genus Culicoides from Manchoukuo with description of a new species (Ceratopogonidae, Diptera). Ins. Mats., 15 (3) : 80-85. -20) 高橋弘 (1955)：北海道の蛙, 蚊, 糠蚊など。新昆虫，8(5):39，一21）竹田忠雄，迎

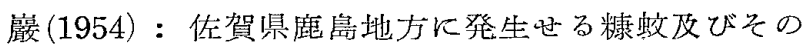
皮膚病について。衛生動物， $5(3 \cdot 4): 86-92$. - 22) Tokunaga, M. (1937) : Sand flies (Ceratopogonidae, Diptera) from Japan. Tenthredo, $1(3): 233$ -343. -23) Tokunaga, M. (1940) : Biting midges from Japan and neighbouring countries, including Micronesian Islands, Manchuria, North China and Mongolia (Diptera, Ceratopogonidae). Tenthredo, 3 (1) : 58-165. - 24) 德永雅明 (1943) : 医 用昆虫学. 一巻，853-926，金原啇店，東京。一-25） Tokunaga, M. (1950) : Culicoides flies from Kyushu, Japan (Ceratopogonidae, Diptera). 䒯生動物, 1 (3) : 64-67. - 26) Tokunaga, M. (1955) : Notes on biting midges from Japan and Korea (Heleidae or Ceratopogonidae, Diptera). Sci. Reports Saikyo Univ., 7 : 1-8. -27) Tokunaga, M. (1956) : Notes on Japanese biting midges (Heleidae or Ceratopogonidae, Diptera). Sci. Reports Saikyo Univ., $8:$ 112-123. 一28) 上野計, 北阔茂男, 不原 忠雄, 矢島朝彥 (1956)：東京都小平町に扣りるヌカ 力の種類, 季節的消長及びその寄生線虫類について. 衞生動物, $7(1): 19-26$. - 29) 矢島朝彥, 北岡茂男, 上野計 (1955)：畜舍に飛来するヌカ力の種類と発生 状態. 得生動物, $6(1): 59$.

\section{Summary}

The work here reported concerns biting-midges collected during the period from May to October, 1956, in Niigata Prefecture, Japan.

Culicoides collected are 14 species (See the list of species).

$C$. arakawae has been widely found over the plains and the hilly regions. C. circumscrptus has been prevalent along the seashore and the area of the saline hot-springs. While, C. matsuzawat was prevalent amongst Okutadami, the mountainous district.

According to our observations on C. circumscriptus at Matsunoyama-village, the larvae have been abundantly found in the slime of the gutter draining, the water which contains $3 \%$ Sod. Chl., $37^{\circ}, \mathrm{pH}$ 8.5-10.0 and was constantly discharging from the saline hot-spring. And the adults attack violently against human beings and their main biting activity reaches a distinct peak at dusk. 